\title{
MEDYADA KANAATLER ÜZERINE: KANAAT ÜRETICILERI DOKSOZOFLAR
}

\author{
Eser KARATAŞ*
}

Gönderim Tarihi: 09.07.2019 - Kabul Tarihi: 01.09.2019

Karataş, E. (2019). “Medyada Kanaatler Üzerine: Kanaat Üreticileri Doksozoflar”. Etkileşim. 4. 254-275.

\begin{abstract}
Özet
Toplumsal kanaatler, gündelik yaşamın şekillenmesi ve toplumun kontrol altında tutulabilmesi açısından egemen güç için hayati bir öneme sahiptir. Kendi egemenliğinin devamını sağlamak ve ideolojisini yeniden üretebilmesi için siyasi erk ile medya arasında sıkı bir ilişkinin ortaya çıkmasına neden olmaktadır. Bu bakımından egemen olanın çıkarı doğrultusunda kanaatler kontrol edilmekte ve kullanılmaktadır. Bu çalışmada, egemen gücün toplumu kontrol altında tutulabilmesi ve medya üzerindeki etkisini anlamak açısından Bourdieu'nün ortaya koymuş olduğu "doxa" ve "doksozoflar" kavramları ele alınacaktır. Bu kapsamda doksozof olarak tanımlanan kişilerin birçok konuda sığ bir bilgi birikimine sahip olmalarına rağmen kanaatleri yeniden üreterek ve bu üretilen kanaatlerin siyasal erkin isteği üzerine ana medya ve yeni medya kanalları aracılığıyla yeniden kurgulayarak nasıl yeni toplumsal pratikler oluşturdukları incelenecektir. Siyasi erkin söylemlerini doksozoflar sayesinde meşrulaştırıp, topluma ulaştırmayı hedefleyen medya, egemen güçle arasındaki ilişkisini kendi çıkarları doğrultusunda korumayı hedefler. Bu durumda medyanın doksozoflar aracılığıyla topluma taşıdığı kanaatlerin ne kadar toplum yararına olduğu sorgulanması gereken bir konudur.
\end{abstract}

Anahtar Kelimeler: doxa, doksozof, kanaatler, iktidar, medya. 


\title{
ON OPINIONS IN MEDIA: OPINION FORMERS DOXOSOPHS
}

\author{
Eser KARATAŞ*
}

Received: 09.07.2019 - Accepted: 01.09.2019

Karataş, E. (2019). “Medyada Kanaatler Üzerine: Kanaat Üreticileri Doksozoflar”. Etkileşim. 4. 254-275.

\begin{abstract}
Social opinions are vital for the sovereign power upon the shaping of everyday life and keeping society under control. It leads to a close relationship between the political power and the media in order to maintain its sovereignty and reproduce its ideology. In this study the concept of "doxa" and "doxosophs", which Bourdieu has put forward in order to understand the influence of the dominant power on the society and its effect on the media, will be discussed. In this context, it will be examined how new social practices are formed by reproducing the opinions and reconstructing these opinions through the main media and new media channels at the request of the political power. The media, which aims to legitimize the discourses of political power through doxosophs and convey it to the society, aims to protect the relationship between the dominant power and its interests. In this case, whether the opinions media convey to society through the doxosophs is in the public interest is a matter of question.
\end{abstract}

Keywords: doxa, doxosophs, opinions, power, media. 


\section{Giriş}

Bugün toplumun inşasında ve kontrolünde büyük rol oynayan toplum mühendisleri, eşik bekçileri ve kanaat önderleri, siyasal erkin ideolojisini yeniden üretip bunları gündelik hayatın pratikleri içinde söylemlerle kullanarak toplumsal kanaatleri denetim ve kontrol altında tutmaktadır. Bourdieu'nün "doxa"ya yüklediği anlam çerçevesinde kanaatleri yeniden üreten dokzosofların, ürettikleri kanaatlerle toplum inşasında ciddi bir rolü vardır. Bourdieu'nün gündeme getirdiği doxa terimini ele alırken, doxa'nın ideoloji ve habitus ile nasıl bir ilişki içinde olduğunu anlamak gerekmektedir.

Habitus, bir insanın yaşadığı sosyal dünyanın içselleştirilmesidir; fakat aynı zamanda sosyal dünyaya ve yapısına da katkıda bulunur. Bu anlamda birey yalnızca biyolojik bir insan değil, bazen tahmin edilemeyecek şekilde aktif olarak cevap veren sosyalleşmiş bir dinamiktir. Bir bireyin içinde yaşadığı durum veya şart habitusun şartlandırılması veya yapılandırılmasında önemli bir unsurdur ve habitus alanın şartlarını ve yapısını yeniden üretir; ancak zaman zaman alışkanlık, bu alanda özellikle toplumsal alışkanlıkları da beraberinde getirir. Böyle bir şartlandırmada ortak alışkanlık kuralları takip ettiğinde ve sağduyu uygulamalarını geliştirdiğinde, sosyal dünya doğal görünür ve bireysel alışkanlıklar habitus içinde kendini rahat hisseder. İşte bireyin sosyal dünyada, habitusun şartlandırılması veya yapılandırılmasında rahatça hareket etmesini sağlayan şey "doxa"dır. Çünkü doxa, birey ve onun içinde yaşadığı toplumsal yapı için bazı şeyleri doğal bir şeymiş gibi göstermektedir. Birçok alanda uzun çaba harcayan doxa, toplum için yeni kanaatler ve bu kanaatler üzerine yeni kanaatler üretir. Ve toplum üretilen bu kanaatler üzerine düşünmediği sürece doxa'yı takip etmelidir.

Doxa'nın ideoloji ile olan ilişkisi ise, ideoloji tarafından yaratılan tüm belirsizliği ve yanlışları kabul etmek zorunda olduğudur. Bu durum aydınlanmış sahte bilincin ortaya çıkmasına neden olur. Baskın ideoloji, sistemin yeni düşünceler üretmeden ve yeni düşüncelere ihtiyaç duyulmadan doxa'lar tarafından yürütülmesini sağlamaktadır. "ideoloji, eski düzenin karanlıkçılığını aydınlatırken toplumun üstüne, insanları bu aydınlığın karanlık kaynaklarını göremeyecekleri ölçüde körleştiren göz kamaştırıcı ışık saçar" (Eagleton, 1991: 101). Doxa, gerçek bilgi ile yanlışı ideoloji tavasında birbirine karıştırıp toplumda sahte bir bilinç oluşturur. Yaratığı bu yeni bilinç ile doxa toplumun bireylerini çok ayrıcalıklı olduğuna inandırır. Böylelikle doxa bilinçli olarak topluma yönelik yaratmış olduğu yanlış kanaatlerle baskın ideolojinin kendi yolunda ilerlenmesini ister. Bu durum baskın ideolojinin söylemlerini toplum nezdinde meşrulaştırıp eleştiri ve muhalefet olma gibi risklerini ortadan kaldırmış olur.

Siyasal erkin kendi ideolojisini yeniden üretip bunu söylemlerle gündelik hayatın pratikleri içinde kullanarak toplumsal kanaatleri kontrol altında tutmak istemesi inkâr edilemez bir gerçektir. Siyasal erkin toplumsal kanaatleri denetim altında tutma isteği onun medya ile sıkı bir ilişki içerisine girmesine 
neden olmaktadır. Medyanın toplum üzerindeki olaylar karşısında rıza yaratma gücü düşünüldüğünde medya, siyasi erk için ideolojik aygıtı olarak hareket eder ve egemen gücün yerini korumasında, muhalif ya da azınlık seslerinin susturulmasında etkin bir rol oynar.

Ayrıca egemen gücün tüm meşru olmayan ideolojilerini toplumu yönlendirerek meşru bir zeminde inşa eder. Böylelikle egemen güç mevcut düzenini sürdürebilir ve koruyabilir. Medya bu amaçla toplum içinde infial yaratmış konuları ana akım medyada ve yeni medya mecralarında habere dönüştürürken, konuların seçiminde, hangi bağlamda incelenmesi gerektiği, vurgu yapılacak yerleri ve üslubu konusunda dokzosofları kullanılır. Farklı sektörlerde faaliyet gösteren medya holdingleri, iktidarla ekonomik ilişkiler içine girmektedir. Bu durum medyayı, siyasal erkin gözcüsü haline getirmektedir. Bu durum haberle gerçeği birbirinden uzaklaştırmakta ve medyayı kamu denetçisi konumundan alıp iktidarın bir kuvveti haline getirmektedir.

\section{Bilgi ve Enformasyon}

İnsan yaşamındaki önemi yadsınamaz olan bilgi konusu gerek mitolojik gerekse gerçek anlamda incelenegelmiştir. Özellikle felsefenin en önemli dalı olan epistemolojiye çok şey borçluyuzdur. Felsefe tarihinde mitolojik düşüncenin etkisi göz ardı edilemez. Örneğin Yunan mitolojisinin, düşüncenin ve evrensel diyalektiğin temsilcisi olan tanrısı Prometheus, yaşadıkları dünyanın yabancısı olan insanları aydınlatmak için Zeus'tan ateşi çalarak bu ateşle insanların aydınlanmasını sağlamıştı. Prometheus mitinde bu ateş aslında bir metafor olarak kullanılmakta ve burada ateş bilgiyi temsil etmektedir. Prometheus aslında Zeus'tan bilgiyi çalmıştı ve çaldığı bu bilgiyi insanlara sunmuştu. İnsanlar böylelikle aydınlanmış olacak ve gerçek bilgiye sahip insanlar artık Zeus'un zalim yasaları altında ezilmekten kurtulup evrenin tüm sırlarını çözmeye başlayacaklardı. Söylenceye göre insanlar için yeryüzü artık karanlık bir yer olmaktan çıkacaktı. Çevresini görüp düşünmeye başlayan insanlar böylelikle Zeus'un keyfi yasalarına karşı durabildi ve bilgi sayesinde yaşamlarını geliştirdi, evrenin sırlarına hâkim olmaya başladı.

Genel anlamda bilgi, süje (özne) ile obje (nesne) arasındaki ilişkidir. Bu bilgi tanımını daha da açmak gerekirse; öznelerin nesneler üzerine düşünerek bir zihinsel etkinlik geliştirmesi olduğu söylenebilir. "Bilme etkinliği, özne ve nesne arasındaki bir süreç iken bu süreç ya da etkinlik sonunda ortaya çıkan ürünün adıdır" (Çüçen, 2003: 4). Burada asıl soru doğru bilginin imkânı ve kaynağının ne olduğu sorusudur. Bir bilginin doğru ya da yanlış olduğunu anlamak için o bilginin gerçeklik ile ne kadar örtüştüğüne bakılmalıdır. Çüçen'in (2003: 8) de dediği gibi; "Gerçeklik düşünceden bağımsız olarak var olan bir durum, olgu veya nesnedir. Gerçeklik, doğruluğu sağlayan varlığın bir özelliğidir. Doğruluk, düşüncenin bir özelliği iken, gerçeklik düşünceden bağımsız olarak var olan bir şeyin özelliğidir". Gerçeklik bir var olma durumuna işaret eder. Yani gerçek olan şey düşünceden hariç nesnel olarak da var olmak durumundadır. Bu du- 
rumda doğru bilginin kaynağı "gerçeklik" denilebilir ve bir şeyin gerçekliği de o şeyin nesnel olarak var olup olmamasıyla ilişkilidir.

Gündelik dilde her ne kadar bilginin yerine birçok alanda enformasyon sözcüğü kullanıyor olsa da bu iki kavran arasında anlam bakımından farklılıklar vardır. Bilgiyle çok fazla karıştırılan ve dilimize Fransızcadan devşirilen information; "danışma, tanıtma, haber alma, haber verme, haberleşme" anlamlarına gelmektedir (TDK, ty.). Günümüzde enformasyon sözcüğü zamanla bilgi kelimesinin yerini almıştır. Enformasyon bilginin aksine daha soyut kavramlara işaret etmektedir ve özneden yani süje'den bağımsızdır.

Enformasyon, her şeyden önce bizden bağımsız, soyut bir şey. Hâlbuki bir yasa benim aklımla ortaya koyduğum, benim fiziksel, biyolojik, psikolojik veya yerine göre toplumsal özelliklerime bağlı olarak ortaya konulmaktadır. Ama enformasyon, belli bir nesnenin adı olmasa da, benden bağımsız olduğunu kabul edebileceğim bir varlığa sahip gibi görünüyor (Ural, 2012: 536-547).

Yine enformasyon, bilginin aksine gerçeklikten uzak çok fazla karmaşık unsuru içinde barındırır, bu da enformasyonun içinde çok fazla manipülasyona uğramış ve dezenforme olmuş unsuru içinde barındırdığını göstermektedir. "Enformasyon çiğ, özgül ve pratik olanı niteler; bilgi ise pişmiş, işlenmiş ya da bir düşünce ile sistemleştirilmiş olanı..." (Çakır, 2018: 23). Bundan dolayı enformasyon denilen kavram belli süreçlerden geçtikten sonra ancak bilginin yerini alabilir. Ural'a (2012: 536-547) göre, "Bilgi, herhangi bir yolla alınan enformasyonun doğruluğunun sınanıp sistemli hale getirilmesidir. Enformasyonun belirli süreçlerden geçip, gerçeklikle örtüştüğünde bilgi oluşmaktadır. Ama "enformasyon=bilgi" denilemez". Enformasyon ve bilgi kavramlarının gerçek anlamlarının dışında kullanılması anlam kargaşasına yol açtığı gibi bu iki kavramın yanlış kullanımı toplumun sınıflandırılmasında da bir karmaşaya yol açmaktadır. Bilgi ve enformasyonun birbirine karıştırılması gibi "bilgi toplumu" ve "enformasyon toplumu" da birbirine karıştırılmaktadır:

Oysa knowledge society'nin karşılığı bilgi toplumu iken, information society'nin karşılığı enformasyon toplumu'dur. Bilgi toplumu ve enformasyon toplumu kavramları arasında çok büyük farklılıklar olmasa da enformasyon toplumu'nu kullanmak daha doğrudur çünkü günümüz iletişim ortamındaki manipülatif ve dezenformatif unsurları da kapsar ki bu unsurlar özellikle internet ortamında günden güne daha da çoğalmaktadır (Çakır, 2018: 23).

İçinde yaşadığımız dünyanın bugünkü görüntüsünün temelinde yatan dünya görüşü ve değerler sisteminin ana hatları, 16. ve 17. yüzyılda Avrupa'da Aydınlanma ile başlayan ve sonrasında bütün dünyayı etkisi altına alan, evrimci ve ilerlemeci, modern, toplumsal değişim anlayışıdır. íkinci Dünya Savaşı'ndan sonraki dönemde meydana gelen değişimlerle birlikte, gelişmiş ülkelerde sanayi toplumunun ötesinde yeni bir toplumsal yapıya dönüşüm yaşanmaktadır. Teknolojik yenilikler, sanayi toplumunu dönüştürürken, ortaya çıkan yeni toplumsal yapıya "enformasyon toplumu" adı verilmiştir.

Enformasyonun iletişim ağları ve veri tabanları sayesinde endüstrinin vazgeçil- 
mezi olacağını ve toplumun siyasal katılım acısından demokrasiye hâkim olacaktır. Çok sayıda geliştirilen yeni leşim aygıtları, iletişim ağları ve çok geniş veri tabanları ile düşsel bir seyahat ve önceden belirlenmiş potansiyel alıcılara, ısmarlama ürünler ve hizmetler sunulacak (McLuhan ve Povers, 2001: 148).

iki kavram arasında farklılıklar olmasına rağmen ülkemizde bu iki kavram çok fazla karıştırılmaktadır ve birbirinin yerine kullanılmaktadır. Tüm bu modernleşme akışı içinde enformasyon ve bilgi arasındaki farkı anlamak için McLuhan'ın enformasyon toplumu tanımına karşılık Daniel Bell'in bilgi üzerine kurulu toplumuna bakmakta yarar vardır. Daniel Bell (1976: 46-49) bilginin "sanayi sonrası toplumların en önemli stratejik kaynağı" olduğunu söyler. Bell, bu söylemiyle sanayi sonrası toplumlarda artık hammadde ve para gibi stratejik kaynakların önemini yitirdiğini vurgulamaktadır: "Bu sebepten dolayı bilgi, gelişmenin ve dünyaya bakış tarzımızı etkileyecek güç, enformasyonun anahtarıdır" (Bell, 1976: 188). Bell'in çalışmalarında "bilgi" her zaman ön plandadır. "Bu yeni toplum, bilgi edinme, işlemden geçirme ve dağıtım konusundaki yeni yöntemleriyle tanımlanmakta ve adlandırılmaktadır" (Törenli, 2004: 32). Bilgi Toplumu'nun çekirdeğini bilgi ve insan oluşturmaktadır. "Bilgi toplumunda en önemli girdilerden insan faktörü ve bilginin niteliğinde değişim ortaya çıkmaktadır. Bilgi, hem kişisel bir kaynak olarak, hem de kilit ekonomik bir kaynak olarak görülmektedir. Günümüzde, bilgi toplumunda ise bilgi anlamlı tek kaynak olarak benimsenmektedir" (Aktan ve Tuna, 1998: 118-134). Özetle enformasyon, yorum, düşünce ve yaklaşım gibi birçok unsuru niteler. Bilgi ise enformasyonun soyut olan şeylerle sentezlenip içleştirilerek, kişileştirilmesi durumudur. Çünkü bilgi insan zihnindeki somut şeylere işaret eder ve sadece hayata geçirilebilir olan şey enformasyon değil bilgidir.

\section{Doxa (Kanı/Sanı) ve Bilgi (Episteme)}

Platon felsefesinin temel dayanağı olan bilgi (episteme) ve sanı (doxa) arasında yaptığı ayrımdan hareketle görünüş ve idealar arasında nasıl bir ilişkinin olduğu konusunda yaptığı açıklamalar, gerçek bilgi ile doxa arasındaki farkı ortaya koymaktadır. Peki, Platon'un bilgi ile sanı arasında yaptığı bu ayrım nedir?

Platon, bilgi ile sanıya aklın iki ayrı durumu olarak baktığı gibi, bu iki durumu karşılayan nesnelere de iki ayrı durumda (hiyerarşik olarak) bakmaktadır. Bilgide Platon için az bilme ya da çok bilme söz konusu değildir. Platon bilgide kesinlik olduğunu bir şey ya da durumun ya bilineceğini ya da bilenemeyeceğini belirtir. Ve bu durum için de yeterli ve zorunlu koşulların olması aksi durumda ise bilgi durumunun söz konusu olamayacağını belirtir. Nitekim Platon'un düalizminin doğasında da sanı düzeyinde epistemeden söz edilemez; aynı şekilde idealar düzeyinde de sanıdan söz edilemez (Demir, 2015: 296).

Platon'un yaptığı bu ayrım bilginin hatasızlı̆ını vurgulamaktadır. Çünkü bilgi idealara dayanır ve gerçektir. Fakat doxa hatalıdır. Doxa idealara dayanmaz ve gerçeklikle hiçbir bağlantısı yoktur. Doxa hem var olan hem de var olmayan olarak gerçek olmayan bilgidir. Demir'e (2015: 296) göre, "Platon için doksa 
hem var hem de var-olmayan ya da yarı var olan algılanan tikellerdir. Tikellere, var-olanlarla ya da gerçek olanlarla (idealar), var-olmayanlar ya da gerçek olmayanlar arasında bir yer vermekte, tikellere yarı gerçektir demektedir". Bu durumda gerçek bilgi idealara yani hakikate dayılıdır. Buna karşılık doxa için ne gerçek ne de gerçek olmayan denilebilir. Bu durumda doxa, bu iki kavram arasında yer alır, yani gerçeklik ve gerçek olmayan arasında bir yerde... Bu durumda doxa soyut olan ve duyumsal, işlenmemiş enformasyon konumundadır. Var olmak ile var olmamak arasında bir yerde olan doxa, insanların sıklıkla inandığı kanaatlerdir. Platon Menon (201: 80-86) adlı eserinde; "doğru sanı ile doğru bilgi arasında fark vardır. Eğer bir kişi bir şeyin gerçek bilgisine sahipse, o kişi doğru sanıya da sahiptir. Ancak bir kişinin doğru sanıya sahip olması, her zaman için gerçek ve doğru bilgiye sahip olması anlamına gelmez". demekteydi. Episteme ve doxa'yı bir zıtık olarak gören ve doxa'yı yanılgının ve yanlışın bir mevcudiyetinin sebebi olarak ele alan Ulus Baker (2015: 60): “Görünüşte, iki terim de nesnel olarak doğru veya yanlış olabilecek fikirlere gönderme yapmaktadır. Ancak belirgin bir farkla: yanlışlık tam da bilimsel bilginin mevcudiyetini önlediği için yanlış bilimsel bilgi diye bir şey olamaz". Bundan dolayı bilimsel olan gerçeklikle sınanmış olan ve doğru olandır. Yukarıdaki tanımlardan anlaşılacağı üzere doxa tamamen kulaktan kulağa yayılan gerçek olmayan, ancak gerçekliği kanıtlanabilir olan duyumsal kanaatler yığınıdır.

\section{Bourdieu Çerçevesinde Doxa'yı Anlamak}

Kanaatler ya da doxa için, gerçekliği ispat gerektiren söze dökülmüş davranışlar biçimi demek yanlış olmayacaktır. Oskay (1973: 16) kanaatlerin bir davranış biçimi olduğunu şu sözlerle açıklar: "Bireyler sorunlar karşısında çözüme ulaşmak için geçmiş deneyimlerine durumla ilgili tutumlarına başvurmayı tercih ederler. Ancak çözüm yolu bulabilmek için durum ve arayış biçimi dışında bu tutumlardan fazla bir fayda elde etmek mümkün değildir". Yüksel (1994: 23) ise, "Kanaatler toplum tarafından benimsenen ortak bir hüküm olarak karşımıza çıkmaz. Aksi takdirde kanaat unsurunu genel olarak kabul ettiğimiz takdirde, bu unsurda yer alan görüş, rasyonel yoldan ispatı gerekmeyen bir hükümdür" demektedir. Doxa, Bourdieu tarafından geleneksel toplumlardaki "doğal" uygulama ve tutumların fenomenolojik bir perspektiften açıklaması olarak kullanılmaktadır. Bourdieu'ye (2000: 16) göre, "Doxa "açık, öz-bilinçli bir dogma biçiminde bile iddia edilmesine gerek olmayan temel bir inanışlar bütünüdür". Bourdieu'nün, bu yaklaşımına göre doxa, deneyimle şekillendirilmiş önceden bilinmeyen, bilinçsiz kalıtımsal ve ilişkisel yatkınlıkları ifade eder. İnsanların gündelik toplumsal etkileşimleri sırasında başkalarının söyledikleri ya da yaptıklarını nasıl anlamlandırdıklarının yansıtılması ile gerçek bilgi arasındaki boşluğu kapattığı bir eylemdir. İnsanların tüm bu gündelik toplumsal etkileşimlerde tutumlarını belirleyen şey birey tarafından içselleştirilmiş "limit duygusu" dur. Kişileri bu limit duygusu girdabında tutan, bireyin göreceli otonom sosyal mikro kozmoslarında (alanların) aracılık ettiği kanaatlerdir. Limit duygusu bu çalışmada, "insanların bireyken yapamadıklarını ve yasaklanmış 
olanları kalabalık olduklarında kendilerine yapma izni vermesi" anlamında kullanılmıştır.

Sosyal çevrede doxa, herhangi bir sorgulama kavramının ötesinde "neyin affedilirse alındığı" ve oybirliğiyle sorgulanamayan başlıca masumiyet halini temsil ediyor. Toplumsal dünyayla doktolojik ilişkide ifade edilen bağlılk, meşruiyetin tanınması yoluyla meşruiyetin kesin olarak tanınmasının mutlak şeklidir, çünkü meşruiyetten dolayı rekabetten kaynaklanan ve bundan dolayı hakaretten ileri gelenleri iddia eden gruplar arasındaki uyuşmazlığın eksikliğinden habersizdir (Bourdieu, 1977: 168).

Doxa, anlaşılır biçimde alan ve habitus ile yakından bağlantılı olan inanç veya görüşleri ifade eder. "Doxa, geleneğin sessiz olduğunu, söylenmeden söylenen olduğunu, bir gelenek olarak kendisi ile ilgili olanın en önemlisi olduğunu söyler" (Bourdieu, 1977: 165-167). Bu tür bir sosyal ortamda, doxa "verilenler için ne alındığı" ile oybirliğiyle sorgulanamayan gerçeklerle ilgilidir. Çünkü herhangi bir soruşturma nosyonunun ötesindedir. "ilkel bir masumiyet hali" ile "mevcut bir söylemin eksikliğinden söylenemeyecek" olan ile bağlantılıdır (Bourdieu, 2000: 24). Doxa ile sosyal toplum arasındaki ilişki yanlış olanın meşruiyetinin tanınmasının mutlak şeklidir. Çünkü meşruiyet kazanmak isteyen gruplar ve buna sahip olduğunu iddia eden gruplar, aralarındaki çatışmalardan dolayı gerçek meşruiyet sorununun farkında değildirler (Bourdieu, 1977: 168). Doxa, toplumsal düzen ile zihinsel yapılar arasındaki ilişkiyi, nesnel düzen ile öznel örgütlenme arasında olan doğal ve sosyal dünyayı sorgulamaz. Çünkü doxa, toplumda duyumsal algının ortaya çıkmasına ve bu algıyla sosyal toplumda sorgulamadan toplumsal eylemlerin ve uygulamaların harekete geçmesini sağlar. Bundan dolayı doxa, doxa'nın kendisini yanlış tanımlamaya devam eder ve kendi kendini doğrular bir şekilde güçlenerek çoğalmaya, sosyal olarak keyfi bir şekilde güç ilişkilerinin doğmasına izin verir.

Doxa, nesnel sosyal yapıların istikrarını, yeniden üretilip, kendilerini bir sosyal aracının algı ve uygulamalarında yeniden üretme yolu ile belirlediği ölçüde belirleyen bir yapı taşıdır; Başka bir deyişle, habitusta alan ve habitus arasındaki karşılıklı pekiştirme, doxanın baskın gücünü güçlendirir; bu da, doxanın içinde bulunan ön varsayımlar aracılığıyla alandaki katılımcıların oyununa uygun "havayı" yönlendirir (Bourdieu ve Wacquant, 1992: 66, 74).

Doxa, yerleşik toplumsal düzenin keyfi söylemsel gerçekleriyle birlikte, toplum bireylerinin içselleştirilmiş sınırlar duygusunu ve gerçeklik duygusunu yanıltarak toplumun gerçeklik algısıyla oynar. Bu biçimde toplum içinde meşruiyetini ilan eden doxa, mantık gerekliliklerine sahip olmayan duyumsal özerk yapısı ile sosyal toplumun güç dengeleriyle ilgili birçok ampirik özelliği de bünyesinde barındırabilir. "Doxa alanın içine gömülürken, alanın (sanatsal alan, dini alan, ekonomik alan, siyasi alan) tanımlanmasına yardımcı olur" (Bourdieu ve Passeron, 1979).

Siyasi alan tarafından toplumun yeniden şekillenmesine yardımcı olan doxa, iktidarın faaliyet gösterdiği ve beklentileri olduğu alanlarda onun meşruiyetsiz tutumlarını söylemlerle meşru kıllar. Böylelikle iktidar karşıtı tutum 
içine giren sosyal grupların muhalif sesleri karşısında yaptığı söylemlerle kamuoyunun desteğini arkasına almış olur:

Modern toplumlarda dil ve dil değişimi ve yanlış tanımlanan keyfi sınıflandırmalar, işledikleri ve yeniden ürettikleri sınıflandırma ve farklılaşma, doxa'nın meşruiyetine katkıda bulunan sembolik gücün kilit unsurlarıdır. Hem maruz kalanların hem de ağlarının, maruz kaldıkları bölümdeki tanınmayan, aktif karmaşıklığı güvence altına alarak sağlarlar (Bourdieu 1991: 34).

Bu durumda doxa'nın dili kullanış şekli bir çeşit öğrenilmiş cehalet biçimidir. Yani hatalı bir tanıma hâkim olan doxa'nın dili kullanış biçimiyle söylemsel ve temsili yönleri güçlendirdiği ve iktidarın tasdikçisi rolüne bürüdüğü bir gerçektir.

Doxa, toplumsal ilişkiler anlamında sembolik güç kavramını desteklemektedir. Bu bağlamda doxa sermaye biçimlerinin aracılık ettiği sembolik iktidar biçimini alarak toplumun daha yoğun bir şekilde sosyal ilişkiler kurduğu eğitim, din, sanat gibi alanlarda meşrulaştırır. Sembolik bir iktidar biçimi olarak doxa kendisine tabi olanlara, kendisinin meşruiyetinin sorgulanmamasını şart koşar. Toplum tarafından içselleştirilen, ama sorgulanmayan normlar ürünü olan doxa toplum nezdinden koşulsuz bağlılık şeklini alır. Doxa çoğunluk tarafından kabul edilen kuralların aksine mevcut düzen hakkında açık bir soruya farklı meşru cevapların verilebileceği bir fikir ortaya çıkarır. Doxa toplumsal yapının içine gömülürken, alanın (sanatsal alan, dini alan, ekonomik alan, siyasi alan vb.) yeniden tanımlanmasına neden olur. Böylelikle doxa nesnel sosyal yapılar ile öznel zihinsel mantığın ilişkisi arasındaki bağın kopmasına ve yeniden tanımlanan alanlarda iktidarın meşruluğuna olanak sağlar.

Kriz zamanlarında toplum içinde infial yaratacak ve iktidar için tehdit oluşturabilecek grupları bastırmak için doxa'lar zaman zaman zayıflatılabilir ve yeniden toplumun algısına göre yeni bir doxa'nın ortaya çıkması teşvik edilebilir. "iktidar tarafından ustalıkla askıya alınan tezlerin toplamı olan doxa'lar pratikte askıya alındıkları zaman geriye dönük olarak yeniden biçimlenerek topluma sunulabilir" (Bourdieu, 1977: 225). iktidar tarafından ustalıkla yeniden biçimlendirilerek toplumun algısına sunulan doxa'ları radikal bir şekilde çözümleyerek eleştirecek birilerinin olmaması, iktidarın meşru olmayan tutumunun sorgulanmamasına ve doxa'ların toplum nezdinde kabul görmesine olanak sağlar. íktidar toplumun sınırlarını doxa'lar ile belirler ve o sınırların dışına çıkılıp iktidarın meşru olmayan tutumlarının sorgulanmasına izin vermez. Sınırlar içine alınmış toplum, olayların perde arkasındaki gerçekleri (kanıtlar, istatistikler, röportajlar, çapraz referanslar) sorgulamak yerine medya araçları vasıtasıyla dokzosofların onlara sunduğu toplumun sembolik tahakküm biçimi olan günlük deneyimlerle ve atıştırmalıklarla her türlü toplumsal olaya duyarlılık gösterdiği hissine kapılır. Toplumsal olaylar karşısında duyarlılık gösterebildikleri hissine kapılan bireyler aynı zamanda eylemde bulunma ve karşı görüş bildirme gibi demokrasi belirtisi olan davranışlara sahip olduklarına da inanırlar. îktidarın, medya araçlarını doksozoflar aracılığı ile ustaca kullanması, 
toplumun neyin örtük, neyin anlaşabilir ve gerçekte neyin ifade edildiği konusunda toplum bireylerini baskılarken, iktidar için daha geniş bir alanda hareket etme imkânı sağlanmış olur.

Doxa bir alanı paylaşılan inançlar olarak kavramlaştırabilir. Bourdieu'ye (1993: 125) göre, "(...) doxa toplum içinde faaliyet gösterenlerin ortak alışkanlıklarını bildiren çeşitli inanç kümeleri içerir. Bu inanç kümeleri kendi temel kuralları, yasaları, söylemsel formları ve normatif inançları barındırır". Topum içinde çeşitlenen bu inanç kümeleri doxa'nın bazı alanları yok saymasına olanak sağlamakta ve yeni alanların ortaya çıkmasına neden olmaktadır. "Yeni alanların ve spesifik koşulların ortaya çıkması, başka alanların yok sayılması veya unutulmasına neden olmakta ve alanlar gittikçe daha özerk hale gelmekte. Özerk hale gelen alanlar neden farklılaştırıldıklarını sorgulamamaktadır" (Bourdieu, 2005: 193). iktidarın, doxa'yı kendi kurallarına göre konumlandırırken yaratmış olduğu bu özerk alanları anlamlandırmak önemlidir. Çünkü aksi takdirde ortaya "heteronomi" durumu çıkar. Yani başkalarınca yapılan yasalara ve konulan kurallara uyulması ve kendini yönetememe, kendi kendine karar verememe durumu gibi. Onun için bu özerk alanlarda toplum bireylerinin diğer sosyal alanlarla, özellikle politik alan, iktidar alanıyla, ekonomik alanla olan ilişkisinin önemini kavramaları gerekmektedir. Brian Rigby'ye (1993: 271) göre, "alanlara ve alışkanlıklara ait sorgulanamayan bir inanç kümesinde etkilenmeyen toplum bireyleri, oyunun asıl kurallarını ve düzenlemelerini sorgulayarak ve oyunun düzeltilmiş uygulamasının sorgulanmasıyla alanların özerkliğini bozabilir". Ulus Baker (2015: 228), üretilen kanaatlerin toplumsal imajlara dönüştürülürken, "İmajların günümüzde insanın zihinsel faaliyetlerini düzenlemekte çok etkili olduğunun farkında olmak zorundayız" der. Doksozoflar tarafından oluşturulan bu imajlar çok hızlı ve anlamlı bir değişim içerisine girer, bu değişim sürecinde imajlar gerçek, bilginin ya da kanaatlerin yerini alarak varlığını sürdürmeye devam eder. Bilginin ya da kanaatlerin yerini alan imajlar ise toplum üzerinde bir standartlaşma mekanizması inşa eder.

\section{Doxa'nın ihaneti: Doksozoflar}

Bourdieu, (2006: 15) Platon'dan aldığı kelimeyi Karşı Ateşler kitabında orijinal hali olan "doxasophus" olarak kullanmıştır. "'Kavram, doxa (sanı) ve etimolojik köken olarak 'sofist' kelimesi Yunanca sophus (bilge, becerikli, zeki) kelimelerinin bir araya getirilmesi ile ortaya çıkmıştır" (Angeles, 1981: 264). Sofistlerin varlık göstermeye başladıkları ilk zamanlarda büyük bir saygınlığa sahip olmalarına rağmen felsefe tarihinde sofist denildiğinde olumsuz bir çağrışım yapmaktadır. Bunun nedeni başta Platon olmak üzere Sokrates'in ve Aristoteles gibi düşünürlerin sofistlere karşı yürüttüğü mücadeleden kaynaklanmaktadır. Bu düşünürler tarafından sürekli eleştirilen sofistler özellikle Platon tarafından metinlerinde para karşılığı ders verdikleri için kazanç peşinde koşan, toplumsal saygınlığını kaybetmiş öğretmen, kâhinler, heykeltıraşlar için kullanımıştır: 
Sofistler, felsefi bir okul oluşturmaktan çok, belli bir mesleğin üyesi olan, toplumsal koşulların değişmesinin doğal bir sonucu olarak ortaya çıkan pratik işlerde yol göstericiliğe duyulan açlıktan, kendileri için bir meslek ve yaşam biçimi üretmiş olup, para karşılığı ders veren gezgin öğretmenlerdi. Bu gezgin öğretmenler, dil bilgisi, ikna sanatı, retorik, mahkemede kendini savunma sanatı, mantık, ahlaki davranış, edebiyat eleştirisi, matematik ve dilsel analiz gibi birçok sanatı öğrenme iddiasında olmuşlardır (Cevizci, 1999: 781).

Bu kavrama popülerlik katan Bourdieu, Platon'un sofistleri eleştirirken ortaya çıkardığı doxasophus kavramının anlamını şöyle özetler: "kendini bilgin sanan ve kanaatler üzerine kanaat üreten görüş teknisyeni" (2006: 16). "Öte yandan siyasal iktidar kendi tasarruflarını mutlak doğru olarak savunurken, aynısını hem medyadan hem de toplumdan beklemektedir" (Parlak ve Değirmenci, 2005: 9-38). Platon gibi nesnelliğin geçerliliğinden şüphe eden Bourdieu (2014: 201), hakikatin "bunları meşru tahakküm ilişkilerine, otoriteye ya da itibara dönüştüren büyülenmiş algı ve kolektif bir kötüniyet etkisiyle bastırılabileceği" konusuna vurgu yapar.

Bourdieu'nün söz ettiği ekonomi, siyaset, din, eğitim, etnik köken gibi özerk alanların sürekli kendini yenileyerek ortaya çıkması medyada faaliyet yürütenlerin de ilgi alanı haline gelmiştir. "Kültürel ve entelektüel alanların özerkliği ve onların özelliklerinin meşruiyeti, medyada bilinçli bir şekilde ideolojiye hizmet eden doxa entelektüellerinin ve medya sahiplerinin daha fazla yeniden var olma ihtiyacına yol açan epistemolojik bir ilişki kazanır" (Bourdieu, 1998: 129). Bourdieu'ye (2006: 16) göre; "toplumda sanılanın aksine devleti savunan ve hâkim kanaati hızla içselleştiren ve bu bağlamda medyanın yeniden üretim sürecinde üstlendiği rolü kanaat teknisyen(liğ)i (doxasophus) üzerinden değerlendirmek mümkündür". Yani iktidarın meşru olmayan tavrını meşrulaştırmak için siyasetçi, iş adamları ve toplumun bireylerini aynı terimler üzerinde buluşturan medyatik sözde uzmanlar sınıfıdır. "Hatta onlar, yerine göre hukuk konusunda birer uzman, demokrasi ve özgürlüklere dair entelektüel donanıma sahip, düşmanın kirli oyunlarını sezebilecek derecede ileri görüşlü-tecrübeli imiş̧̧esine hareket edip, bütün bu meziyetlerini hemen her yazı ve sözlerinde tekrarlaya gelen oyunculardır" (Parlak ve Değirmenci, 2005: 9-38). "Çünkü bu süreçte medya, hâkim yapının ekonomik, toplumsal ve siyasal gündemini halka aşılamak ve bunları savunmakta önemli rol oynar" (Herman ve Chomsky, 1998: 100). Doksozoflar medya aracılığıyla sergiledikleri tüm tutumların sonuçlarının nereye varacağını bilen ve bilinçli bir şekilde bu tutumları sergileyen birer kanaat uzmanıdır. Parlak ve Değirmenci'ye (2005: 9-38) göre, "hangi tür eylem, davranış, söz ya da tutumun suç teşkil ettiği, suçun niteliği ve sabitliği, özgürlük ya da demokratik sistemi nelerin aşındırdığı ya da güçlendirdiği vb. pek çok konuya bir kriminoloji uzmanı derecesinde hâkim de olabilirler". Bourdieu (2013: 24) bu medyatik olan sözde uzman sınıf (doksozoflar) için, toplumsal olaylara iktidarın gözlüklerinden de baktığını söyler: "doksozoflar belli şeyleri görürken bazı şeyleri görmezler ve gördükleri şeyleri iktidarın çıkarına olacak şekilde görürler, ayıklarlar bu ayıkladıkları şeyleri yeniden kurgulayıp toplumun inşasında kullanırlar". Kanaat teknisyenliğinin temelinde de, iktidarın ey- 
lemlerini meşru kılmak yatar. Bourdieu'nün (2000: 33-34) Televizyon Üzerine adlı kitabında fast-thinker olarak adlandırdığı "uzman yorumcular toplum koşullarının yeniden inşasında bir tür ideolojiye işaret eder ve medyadaki tüketim alışkanlığı kavramlarla ilişkilidir". Parlak ve Tangün'e (2018: 12) göre, "kanaat teknisyenleri neolibarel evrede toplumun büyük kısmı haklarının gasp edilmesi eşanlamlı sayılabilecek tasfiye sürecini, söylemlerle doğallaştırıp bir "kader, fıtrat" haline getirebilir". Kader ve fitrat haline getirilen doxa'nın dolaşıma girmesiyle ilgili olarak Göker (2011: 69) şunları söyler: "Zengin bir anlatının ürünü olan ve içerik yönünden zengin olarak üretilmiş teoriler inanmanın ve onları kollamanın getirdiği pratik faydalar, üretilmiş teorinin yoğun dolaşıma girmesi ve medya, yayınevleri gibi dağıtım örüntüleri tarafından desteklenmesi, işte tüm bunlar bir büyünün unsurlarıdır". Doksozoflar tarafından toplum içinde infial yaratacak durumların ortadan kaldırılması ve olayların iktidarın çıkarına olacak şekilde yeniden üretilmesi aslında egemen olanın tek tipleştirme ve bir arada kalma çağrısının ürünüdür. Daima iktidarı takip eden ve konumlarını ona göre ayarlayan doksozoflar Alpan'a (2014) göre, “(...) bir tür 'negatif söylem entelektüeli'dir. Bu düzen sınırları içerisinde durup entelektüel kimliğini korumak isteyen birinin önünde tek bir çıkış yolu vardır: Negatif entelektüellik". Toplumsal yapı içine gömülmüş, uyuyan doxa'lar medyanın hazırladığı zeminlerde doksozoflar tarafından manipüle edilerek ve değişen koşullar da göz önüne alınarak toplumun çözüm arayışlarına göre tekrar tekrar kendini yenileyerek var olurlar.

Negatif entelektüel, inanç ve önceliklerini devlete göre hizalayan, düşünce sistematiğinin merkezinde iktidarın çıkarlarına hizmet yer alan ve attı̆ı̆ her adımda iktidara yakınlaşmayı gözeten bir "aydın"dır. Negatif entelektüelin muhalefet etme, isyan etme, direnç gösterme ve karşı çıkma yetenekleri tümden ortadan kalkmıştır. Medya tarafından orkestrasyonu yapılan büyük manipülatif operasyonlarda başrol almaktan gocunmazlar (Alpan, 2014).

Doksozoflar entelektüel bir brikime sahip oldukları izlenimi vermek için yaşanan şeyleri ve iktidarın olmasını istediği şeyleri basit kategorilere hapsederek egemen olanın kavram ve dilli ile yeniden üretirler. Doksozofların, sistematiği karmaşık toplumsal yapılara karşın basit bir düşünce sistematiği vardır. Doksozofların bu basit düşünce sistematiği, toplumsal süreçleri iktidar lehine basitleştirmeye dayanır:

Doksozoflar, sorgusuzca kabul edilmesi beklenen düzenin temel dayanaklarının reddinde bir siyasî önyargı görürler. Bu temel dayanakların topluma dayatılması ise son derece doğaldır. Bu nedenle düzenin devamını sağlayan argümanları kullanarak, gündemlerin düzenin temel paradigmasının dışına çıkmadan basit karşıtlıklar içine sıkıştırılarak tartışılmasını onaylarlar. Bu tartışmaların istenilen doğrultuda ilerlemesini sağlayacak "düzen memurlarıdır" doksozoflar (Alpan, 2014).

Başka bir deyişle iktidarın var olan düzeninin devamlılığını sağlamak için görevli doksozoflar, medyanın hazırlamış olduğu zeminlerde iktidarın meşru olmayan faaliyetlerinin istenilen yönde meşru kılınması için toplum içine gömülü doxa'ların iktidarın çıkarları doğrultusunda anlamlar üretmesini sağ- 
lamakta görevli kolluk kuvvetidir. "Kanaat teknisyenliğinin temel misyonu, düzenin devamını sağlayacak argümanların toplumsal manada kabul görmesi için yeterli sıklıkta tekrarlanmasını sağlamaktır. Tüm aksi verilere karşı iktidarın mazlumların temsilcisi olduğu yönündeki algının canlı ve kuvvetli kılınması, doksozofların iş tanımında mevcuttur" (Alpan, 2014). Doksozoflar toplum ile iktidar arasındaki ilişkiyi sürekli canlı tutmak için iktidarın, toplumun varlığını ve güvenliğini sağladığı yönünde çeşitli kodlamalara ve imgelere işaret eder. Bu kodlar ve imgeler tamamen toplumun inanç algısına yöneliktir. Bu bağlamda doksozofların toplumun algısını bir tür pratik bir inanç silsilesine dönüştürdüğü söylenebilir. Türk'e (2016: 614) göre "doxic düzen, hâkim ve tabi olanlar arasındaki ilişkiyi sembolik iktidar ve şiddet vasıtasıyla hep canlı tutmaktadır". Alman Sosyolog Hans Speier'ın kamuoyu olgusunu ele alan Katz'a (2000: 123) göre de, iletişim süreci iki aşamalıdır; "iletiş̧imin ilk aşamasında toplum bireyleri toplumsal sorun ve konularda birbirine ters düşen görüş ve inançları tartışır ve fikir alışverişinde bulunurlar. İkinci aşamasında ise toplum bireyleri arasında geçen tartışma ve fikir alışverişlerinin sonucunda baskın gelen kanaat iktidara aktarılır". Bu durumda Speier'ın kamuoyu olgusuna göre, toplumsal sorunlar üzerine geçen tartışma ve fikir alışverişi sürecinde iktidar devre dışı bırakılmıştır ve bu süreçte ne iktidarın ne de iktidarın kolluk kuvveti görevini üstlenmiş doksozofların hiçbir şekilde görüş bildirmemesi gerekir.

Doksozofların yeniden var olma çabalarına karşı koyabilmenin en etkin yolu Bourdieu'ye (2000: 188) göre, "gerekli bilgi birikimi seviyesi korunmalı ve hatta yükseltilmeli, gerçek bilgi sahiplerinin özerk alanlara özellikle siyasi alana girmesine olanak sağlanmalı ve uygun epistemolojik koşullarda üretilen bilginin paylaşım ve erişim kolaylı̆̆ı olmasından geçer". Doksozofların, iktidarın meşru olmayan tutumlarını meşru kılmalarının önüne geçmenin bir diğer yolu ise ifade ve eleştiri araçlarının (gazete, dergi, TV, sosyal medya mecraları vb.) bilgi üretmelerine olanak sağlamak ve herkesin bu araçları eşit şekilde kullanabilmesinin önünü açmaktan geçmektedir. Bourdieu (1988: 12) Homo Academicus'ta bu konuyla ilgili şöyle der: "Paradoksal olarak, bilimsel gerçeğin üretilmesi için uygun koşullar ancak bilimsel alandaki eleştirel mantık çalışmalarının yaygınlaştırılmasıyla mümkün olur". Böylelikle toplumsal sorunlar üzerine tartışmalarda bireylerin düşüncelerini ifade etme özgürlüğü elde edilecektir.

\section{Doksozofların Medya içindeki Rolü}

Son dönemde gelişme gösteren kitle iletişim araçları, çeşitliliği bakımından kitlesel iletişimin önünü açmış ve daha geniş kitlelere ulaşma imkânı sağlamıştır. Bu durum ise medya teknolojilerine bağlı toplulukların oluşmasına yol açmış ve kitle iletişiminin ortaya çıkmasını neden olmuştur. Bu topluluklara iletişim olanağı sağlayan teknolojiler çeşitlilik göstermektedir. Bu araçlar radyo, TV, film, gazete, dergi ve son zamanlarda popülerliği artan görsel-işitsel olarak, toplumun her kesimden bireyin aktif olarak katılım sağladığı ve hem bilgi hem de eğlence olanağı sağlayan sosyal medya platformlarıdır. Tüm bun- 
ların yanı sıra medya araçlarının bir diğer görevi ise medya mesajları üretip bunların daha geniş kitlelere ulaşmasını sağlamaktır. 'Teknolojik Determinizm Teorisi'nin kurucularından olan Gabriel Tarde'dan aktaran Katz, (2000: 123126) "(...) mesajdan çok aracı yücelten medya, yalnızca bilgi dağıtıcısı veya gündem tedarikçisi değil; aynı zamanda ulus inşasının güçlü bir failidir" der. Bu araçlar sağladıkları bilgi ve eğlencenin yanı sıra topluma mesaj verme çabaları 1940-1960'ların başlarından beri medya araştırmalarına konu olmuştur. Bu araştırmalar sonucunda kitle iletişim araçlarının ve medya kültürünün, toplum bireylerinin tutum ve davranışlarında ne gibi etkileri olduğuna dair teorilerin ortaya çıkmasına olanak sağlamıştır. Bu teorilerden biri de toplum bireylerinin sosyo-psikolojik, işlevselci yönünün araştırılmasına neden olan Paul Lazarsfeld'in 'Sınırlı Etkiler Teorisi'dir.

1940-1960'ların başlarında kitle iletişimin etkinliği ve etkileri konusunda sosyo-psikolojik, işlevselci kuramın ön plana çıkıı̆ı görülür. Özellikle ABD'deki öncü iletişim bilimciler Harold Lasswell, Paul Lazarsfeld, Joseph Klapper, W.Shramm bu kuramlar çerçevesinde kitle iletişim aracı içeriğinin tutum ve davranışlar üzerindeki etkisini, bireysel farklııklarla açıklamaya çalışılar (Yıldız, 2014).

Lazarsfeld, 1940 yılında Amerika'da gerçekleştirilen seçimlerde kitle iletişim araçlarının seçmen üzerindeki etkisini araştırmaya yönelik bir çalışma yapmıştır. Lazarsfeld yaptığı bu çalışmanın sonucunda sadece tek başına kitle iletişim araçlarının seçmen üzerinde etkisinin çok az olduğunu fark eder. Erdoğan'a (2005) göre Lazarsfeld'in çalışmasındaki bu durum aslında "sınırlı etki ve medyanın gücünün güçsüzlüğü"nü ortaya koymaktadır. "Çünkü etki kişiler arası ilişkilerden, kapı tutuculardan, fikir liderlerinden geçerek olmaktadır. Dolayısıyla, sistemin medyası, sistemi satmakta ve "aptallar kitlesi" yaratmakta etkin bir güce sahip değildir" (2005: 1-48). Lazarsfeld, 1940 yılında yaptığı bu çalışma sonrası önemli bir kuramı ortaya koyar. Bu kuram 'iki Aşamalı Akış Kuramı'dır. Bu kurama göre fikirler kitle iletim araçlarından doksozoflara oradan da medya tüketicisi konumundaki geniş kitleye ulaşır. Lazarsfeld'in 'iki Aşamalı Akış Kuramı' ile birlikte medya çalışmalarında "kapı tutucu ve kanaat teknisyenliği" kavramları daha bir önem kazandı. Çünkü kitle iletişim araçlarından verilen mesajların kanaat teknisyenlerinin aracılığı ile topluma iletilmesinin mesajın etkisini artırdı̆̆ı anlaşıldı. Medya toplumun gündemini belirlemede çoğu zaman istediği görüş algılanana ve algılanmasını istediği görüşü gerçek olandan uzaklaştırana kadar, çeşitli haber medyalarında ve sosyal paylaşım sitelerinde doksozoflar tarafından tekrarlanır. Böylelikle toplumda, doksozofların ortaya koyduğu gündem esas gündem olarak kabul edilir ve o gündem etrafında toplumun kanaatleri oluşur.

Kitle iletişim aracından verilen mesaj, doğrudan bireye gitmeden önce fikir liderlerine ya da grubun sözcüsüne ulaşarak bir kırılmaya uğrar. Bu kırılma sonucunda sözcünün de etkisiyle mesaj kabul ya da reddolunur. Burada fikir liderinin önemi ortaya çıkar ve mesaj iki aşamada akışkanlık kazanır (Baran, 1997: 65).

Lazarsfeld' in kuramına göre, kitle iletişiminde akış tek yönlüdür. Ancak araya kanaat teknisyeni (doksozof) girerek ikinci aşamayı oluşturur; böylelikle 
doxa ve onun verdiği etki düzeyi bu kanaat teknisyeninin süzgecinden geçerek artırılmış olur. Doksozof kitle iletişim sürecinin en önemli öğesidir ve kitle iletişim araçlarını iktidardan daha çok kullanır. Parlak ve Tangün'e (2018: 13) göre doksozoflar; "tam bir teyakkuz halini çeşitli damgaları, kodlamaları ve imgeleri kullanarak söylem düzenine indirip sembolik şiddete dönüştüren ve sembolik iktidarı üreten güvenlik politikası unsurlarıdır". Medya-toplum-iktidar arasında yaşanan tüm bu ilişki aslında doksozofun kendince olan biteni anlattığı ve kendiyle uyumlu bir medya tüketimine işaret eder. Doksozofların toplum içerisindeki statüsü medya tarafından popüler düşünce ve prestijle eşleştirilmiştir. Bu durumda doksozofların işlevi "okuyucu için bir başlangıç noktası tayin etmesi, 'şeylerin düzenini' temsil etmesidir" (Parlak ve Yıldırım, 2014: 26-27). Diğer bir deyişle doksozoflar tarafından üretilen doxa'lar, toplum için akıl yürütmeme ve medya aracılı̆ı ile belli bir hattı takip etmek üzere kurgulanır. Bu durumda doxa'lar üzerine düşünme gereksinimini ortadan kaldırır ve bunun sonucunda medya tarafından belli bir hat içinde kalan toplumun fikri sabitlenir. Göker'e (2011: 67-68) göre, "sabit fikir olarak kendisine tabi olan kişilere bir pratik inançlar seti ve bu inançları gerekçelendirme nedeni sağlar". Bu durumda doksozoflar tarafından medya aracılığı ile oluşturulan sabit fikirlilik, toplumun hafızasının inşasına ve toplumun yeniden kurgulanmasına olanak sağlar. Bu nedenle iktidarın meşru olmayan tutumu medya okuyucuları tarafından mantık çerçevesinde değerlendirilemez.

iktidarlar, kitlesel medya araçları ve doksozoflar aracılığı ile topluma vermek istedikleri mesajlar ve bu mesajların içine yerleştirdiği yorumlar ile toplum üzerinde tahakküm kurmayı hedeflerler. George Orwell'in (2001: 33-34) Bin Dokuz Yüz Seksen Dört adlı eserinde "Büyük birader bizi gözetliyor!" sözü aslında iktidarın toplum üzerindeki kontrolünü sağlamak için yaptıklarının özeti gibi: "(...) Winston, her bildirinin gereklerini yerine getirdikten sonra, konuş-yazılmış düzeltmeleri Times'ın gerekli sayısına iliştirip basınçlı hava borusuna koyuyor, sonra da yerleşmiş bir alışkanlıkla, bildiriyi ve kendi tuttuğu notları alevler tarafından yutulmak üzere, okuyucunun bellek deliğine atıyordu". Orwell, aslında burada medyanın gerçekleri ve doğruları birbirinden ayırarak saptırdığını, iktidarın söylemlerinin arasına yeni mesajlar ekleyerek bunu topluma yutturduğunu söylemekte. Oysaki medyanın, iktidarın söylemek istediklerine dair varsayımlardan başka bir rehberi yoktur. Tüm her şeyin iktidar tarafından denetiminde olduğu, konuşma özgürlüğünün yok edilip muhalif seslerin susturulduğu, toplum tehlikesine karşı yürekten bir mücadeleye girişen medya toplumun bilinç alanını daraltarak iktidarın tahakküm sürecinde önemli rol oynamaktadır.

Gerek duyulan her kavram tüm eşdeğer sözcüklerinden sıyrılarak, anlamı kemikleştirilmiş tek bir sözcükle anlatılacak. Sözcük sayısı her yıl biraz daha azalacak ve bilincin alanı her yıl biraz daha daralacak. Şimdi bile, düşünce suçu işlemek için ne bir neden, ne bir özür var. Tüm iş, kendini biçimlendirmek ve gerçeği denetleyebilmek. Ama sonunda, buna da gerek kalmayacak. Dil yetkinliğe ulaştığı zaman devrim tamamlanmış olacak (Orwell, 2001: 42-43). 
iktidar ve medya birbirinden ayrı düşünülemez. Çünkü iktidar, toplumu denetim altında tuttuğu gibi medyayı da denetim altında tutar. Birçok ülkede medya yayınları iktidarlar tarafından düzenlenir ve sınırlandırılır. Sözeri'ye (2005: 23) göre, "gazetecilerin meslek etiği alanında tartışmaları ve özdenetim mekanizmaları yoluyla çözmeleri gereken pek çok konunun yasaklar yoluyla düzenlenmeye çalışııması basın üzerinde hissedilen baskıyı arttııı niteliktedir. Bununla birlikte siyasi kutuplaşma da basında meslek içi dayanışmayı ve özdenetim mekanizmalarının etkinleştirilmesini engellemektedir". Ayrıca medya sahiplerinin, medya dışında başka alanlarda ekonomik faaliyetler yürütmeleri yine iktidarın medya üzerinde baskı ve denetim kurmasına neden olmakta. "Türkiye'de medya kuruluşlarının sahibi holdinglerin çıkarlarının gazetecilikten çok daha geniş alanlara yayılmış olması. Bu nedenle hükümetlerin her zaman medya sahiplerini zorlayacak yöntemlere sahip olduğunu gösteriyor. Ekonomik çıkarlar üzerinden tehditler çok önemli. Özellikle ekonomide düzenlemeler ve hükümet kararları kar oranları üzerinde büyük etkiye sahip" (Jones, 2013). Sözeri ve Kurban'a (2012: 47-105) göre, "Medyanın piyasa sistemi ile daha fazla bütünleşme yönündeki eğilimleri, medyanın tekelleşmesini ve bir şirketin bir veya daha çok sayıda gazete, TV ve radyoya sahip olması anlamına gelen çapraz mülkiyeti arttırmıştır". Bu durum birçok totaliter rejimde olduğu gibi, medya üzerindeki sansürün geniş kapsamlı biçimlerine kadar çeşitlilik arz edebilir.

iktidarın baskısı altındaki medyanın, onun hegemonyasının devamını sağlamak ve yine onun meşru olmayan davranışları yüzünden toplum içinde oluşan çatlakları onarmaktan başka çaresi yoktur. Bunun için medya doksozoflar aracılığı ile iktidarın kullandığı dillin aynısını kullanarak iktidarın ideolojisini her gün yeniden üretmektedir. "Medyanın 'toplumsal amacı' topluma ve devlete egemen ayrıcalıklı grupların ekonomik, toplumsal ve siyasal gündemlerini halka aşılamak ve bunları savunmaktır" (Chomsky ve Herman, 1998: 100). Neumann'a (1998: 226) göre, doksozoflar tarafından medya aracılığı ile doğallaştırılan ideolojiler aslında "iletişimsel alanda doğal gibi gösterilen ideolojiler soyunuk değildir, aksine egemen olanın ideolojisi tam olarak bu doğalıkta saklıdır". Walter Lippman 1922 yılında yazmış olduğu Kamuoyu (Public Opinion) adlı kitapta medya ve doksozoflar tarafından doğallaştırılan egemen olanın ideolojisine dair toplum bireylerinin kafasındaki fotoğrafı ortaya koyar:

Haberin onlara ne kadar hızlı ya da yavaş ulaştığı ile ilgili fikir sahibi olabilmeleri bilgilerin gerçek olduğuna inanma eğilimlerini değiştirmez. Kişilerin dünyadaki devletler hakkındaki düşünceleri onlara ulaşan bilgiler doğrultusunda şekillenmektedir. Aynı şekilde tanınmış kişiler hakkında bildikleri de kurgulanmış bir gerçekten başkası değildir. Bu düşünceye göre gerçek anlaşılan şeyin merkezindedir, sosyal gerçeklik anlaşılanın dışına çıkamaz (Lippman, 1993: 138).

Lippman'ın, (1993: 138) "sosyal gerçeklik anlaşılanın dışına çıkamaz" dediği şey medya ve doksozoflar tarafından belirli basmakalıp söylemler ve basite indirgenmiş imgelerle oluşturulan klişe gündemdir. Doksozoflar medya araçlarıyla oluşturdukları klişe gündemler sayesinde toplum için artık gerçekliğin 
ne olduğunun bir önemi yoktur. Çünkü artık önemli olan toplumun beklentilerinin ve ümitlerinin bu klişe gündemler tarafından karşılanmasıdır. Luhmann'a (2000: 36) göre, medya tarafından doksozoflar aracılığı ile beslenen toplum için "Nelerin acilen ele alınması lazım? Herkes neyi tartışıp konuşmalı? Bütün bunlara medya karar verir". Bu bağlamda klişe gündemler düşüncelerimizi şekillendirir ve doksozoflar tarafından toplumsal kanaatler belirlenmiş olur. Doksozoflar tarafından oluşturulan medyatik kanaatlerin asıl amacı, toplumsal rıza üretmektir:

On dokuzuncu ve yirminci yüzyıllarda inşa edilen "fikirler pazarı", alt sınıfların ideolojik ve kültürel bağımsızlığını yok ederken, fiilen üst sınıfların inanç ve fikirlerini yaymaktadır. Bu durum sosyo-ekonomik konum ile ideolojik güç arasında sağlam ve kalıcı bağlar kurmaya zorlanmış, üst ve üst-orta sınıfların fikirler pazarına egemen olma becerisi, genellikle bu katmanların bütün toplumun politik gerçekliği algılayışını ve gerçekçi politik ve toplumsal olanaklar yelpazesini şekillendirmesini sağlamıştır (Chomsky, 1998: 103).

iktidarın nesne olarak gördüğü toplum, iktidarın zorunlu ihtiyaçlarını büyük ölçüde karşılamış, gerçeklik ve mantıksal düşünme yeteneğini yitirmiş bir insan topluluğudur. Çünkü medya doksozoflar aracılığı ile toplumun gerçeklik algısını simüle etmiştir. Yani artık toplum sahip olmadığı şeylere sahipmiş gibi hisseder. Böylelikle medya araçları tarafından topluma doğru bir akış şeklinde gönderilmiş ve toplum içinde dolaşıma girmiş mesajlar toplum tarafından aidiyet duygusu ile sahiplenilir. Baudrillard'a (2015:15) göre, "bundan böyle her türlü düşsel ve gerçek ayrımından yoksun, yalnızca aynı yörünge çevresinde dolanan modellere dayalı ve farklılık simülasyonu üretiminden ibaret bir hipergerçekten söz edebiliriz". Bu durumda medya toplum için gerçeklikten uzak, gerçek olmayanların gerçekmiş gibi gösterildiği bir simülasyon evreni oluşturmuş olur. "Simülasyona ait olan hipergerçek, gerçeğin kendine benzemesine neden olmaktadır. Hipergerçeğin ya da simülasyonun insanları her türlü ilke ve amaçtan caydırabilme özelliği, onun tehlikeli olan diğer bir yönüdür" (Öker, 2003: 216). Doksozoflar tarafından medya aracılığı ile yaratılmış olan bu simülasyon dünyası içinde toplum bireyleri için azalan gerçekliğin yerini kendileri tarafından üretildiğini sandıkları kanaatler almaktadır. Toplum bireyleri, içinde kendi kanaatlerinin olduğunu sandıkları medya içeriklerine koşulsuz bir inançla bağlanırlar. Böyle bir durumda medya içerikleri toplumsal sorunlara eğilmek yerine bir iletişim oyunu ortaya koyar. Sorun çözmek yerine, sahneye koyduğu oyunla sürekli anlam üreten medya bir iletişim oyunu içinde kaynayıp gider. Bu simülasyon oyunun gerçekliğini kanıtlayabilmesi için medya içeriğinin sürekli kendini yenileyerek doksozoflar tarafından tekrar edilmesi gerekir. Zaten medya içeriklerine inanılmasının altında da bu yatmaktadır. Medya içeriklerinin sürekli kendini yenileyerek tekrarlanması toplumsal yapının ayrışmadan, bir arada kalmasına olanak sağlamaktadır. Böylece medya içeriği hem "anlamını" hem de "toplumu" anlamsızlaştırmaktadır. Anlama ait tüm gerçekliklerin iktidara hizmet eden doksozoflar ve medya araçları tarafından yutulması, anlamın zedelenmesine ve toplumun şekillendirilmesinde anlamın varlığına işaret eder. Medya, iktidarın bu yolla toplumu ele geçirip meşru olmayan tutumlarını 
meşru gibi gösterdiği ve dokozoflarla kesişme noktasıdır.

\section{Doksozoflar Olarak Yeni Mecralar: Sosyal Medya}

Bilgi akışının ağlar üzerinden hızlı bir şekilde sağlanabildiği günümüzde hem bilginin hem de iletişimin formu hızla değişmektedir. Kitle iletişim araçlarından biri olan ve toplum bireylerinin zamanlarının büyük bir bölümünü geçirdikleri dijital medyanın varlığı "yeni dönem doksozoflar"ın ortaya çıkmasına neden olmuştur. Medya içeriklerinin gelişen iletişim teknolojileri sayesinde kolayca üretilebilir olması doksozofların daha etkin ve hâkim olduğu mecralarında değişim göstermesine neden olmuştur. "Başta Facebook ve Twitter olmak üzere sosyal ağlar fikirleri yaymak, yandaş toplamak, sosyal hareketleri mobilize etmek ve organize etmek adına yoğun şekilde kullandığı mecralardır" (Turhan, 2017: 26-44). Doksozoflar tarafından sosyal medya platformlarında üretilen gündem belirleyen içerikler haber medyasında da kolayca yer bulabilmektedir. Sosyal medya platformlarında gün içerisinde viral olan bir paylaşım çok hızlı bir şekilde haber medyasının konusu da olabilmekte. Böylece doksozoflar sosyal medya platformları sayesinde, toplumdaki bireyler ile iletişim kurup, etkileşime geçtikleri ve kamuoyu oluşturma çabaları çerçevesinde kendilerine yeni bir alan bulmuşlardır. Sosyal medya bu açıdan her geçen gün etki alanını artıran güçlü ve genişleyen bir kitle iletişim aracı haline geldi ve sosyal medya platformları kitlelere ulaşılabilirlik açısından çok daha kolay ve ucuz bir alan halini aldı. "Bir lüks olmaktan çıkan internet kullanımı, günümüzde herkesin talep ettiği, farkındalığını ve statüsünü bu sayede genişlettiği bir yeni benlik ifade yolu haline gelmiş bulunuyor" (Keleş, 2012). Ayrıca doksozoflar, iktidarın sahip olduğu sosyal medya hesaplarından yapılan paylaşımlara kendi yorumlarını ekledikten sonra yeniden paylaşıma açarlar. Bu durum ciddi bir yönlendirmeyle birlikte iktidarın düşüncesinin paylaşıma açık, yorumlanabilir ve tepkici bir sisteme dönüşmesine neden olur. "(...) hareketlere yön veren spesifik hesaplar büyük etkiye sahip olabilmektedir. Bu tip hesapların, liderlik ve sürükleyicilik vasıfları daha büyük önem kazanmaktadır" (Turhan, 2017: 26-44). Böyle bir durumda daha önce değinilen Lazarsfeld' in 'iki Aşamalı Akış Kuramı' genişleyerek dört aşamalı bir akışa geçmiş olur: asıl mesaj ('ilk paylaşan'), yorumlayan ve yeniden dolaşıma açan ('doksozof'), mesajı alan ve yeniden yorumlayan ('okuyucu, takipçi, beğenen') ve yeniden mesajı paylaşan ve dolaşıma açan ('okuyucu'). "Sosyal medya dediğimiz ortamlar gazete haberlerinin yayılımının hızlanması açısından önemli bir role sahiptir. Sosyal medya da okuyucuların ne düşündüklerinin ve yorumladıklarının takip edilmesi açısından da bir o kadar önemlidir" (Sütçü ve Bayrakçı, 2014: 39-53). Kınık'a (2013: 76) göre ise, "sanal ortamda üretilen herhangi bir mesajın, fikrin, içeriğin diğer kullanıcılarla eş zamanlı bir şekilde paylaşımını sağlayan sosyal medya, iletişim olgusunun önemli bir öğesi olan geri bildirimin hızlı ve doğrudan alınmasını sağlar".

Sosyal medyada faaliyet gösteren doksozofların hedef kitlesi geleneksel medyadaki hedef kitlesinden farklıdır. Doksozofların sosyal medya platformlarındaki hedef kitlesi "networked audience" diye adlandırılan ağ tabanlı he- 
def kitledir. Doksozoflar için bu yeni hedef kitle sosyal medyayı aktif kullanan, sorgusuz sualsiz içerikleri yeniden paylaşan, yorumlayan birbirleri ile bağlantılı sıkı takipçilerdir. Doksozoflar, bu ağ tabanlı kitleyi tamamen rakamlara indirgemiştir, onlar için tek önemli olan bu kitlenin arkadaş listelerinde kaç kişi olduğu, takipçi sayıları vb. gibi konulardır. Bu sebepten dolayı doksozofların sosyal medya platformlarında ne kadar çok takipçisi olursa, fikirlerini yayma ve sosyal medyada kabul görmelerinin önü o kadar çok açılmış olur. "İnsanların anında tepki verme, beğenme, paylaşma, yorum yapma gibi etkinliklere sahip olması, kanaat önderiyle bire bir ilişki kurmasını sağlarken, hem destekleyici hem de karşı tepkilerin ortaya çıkmasını kolaylaştırıcı bir kitle iletişim yönteminin doğmasına neden olmuştur" (Keleş, 2012). Sosyal medya platformlarında fikirlerine önem verilen doksozoflar, ortaya çıkan bu dört aşamalı akışkan yapısallığın oluşumuyla mesajlarının daha güçlü olarak ilerlemesini sağlarlar. Ayrıca sosyal medya üzerinde içerik üreten doksozoflar için hayranların ilgisini çekmek artık bir iletişim meselesi değil, kişiler arası ilişki haline dönüşür. Sonuç olarak sosyal medya platformları kitle iletişimine yeni bir soluk getirirken, doksozoflar için de iktidarın fikirlerini yayabilecekleri, daha geniş kitlelere daha hızlı ulaşabilecekleri yeni mecralar haline gelirler.

\section{Sonuç}

Bu çalışmada doxa kavramı Bourdieu'nün ona yüklediği anlam çerçevesinde analiz edilmeye çalışılmıştır. Ayrıca çalışmanın temelini oluşturan doxa kavramından türeyen, Platon'un "doxasophus" diye adlandırdı̆̆ı kendini bilge sanan kanaat teknisyenleri doksozoflar'ın, egemen olana hizmet etmek üzere, toplum tarafından sorgulamayan, üzerine düşünülmeyen ve fikirlerin inançlara dönüştüğü bir dünyada nasıl rol aldıkları ortaya konulmaya çalışılmıştır. Bu bağlamda iktidarın toplum üzerindeki tahakkümünü artırmak ve meşru olmayan davranışlarını meşrulaştırmak için doxa'nın ihaneti olan doksozofların ve medyanın siyasal erkin baskısı ve etkisinde kaldığının açık bir göstergesidir. Bütün bu tanımlar çerçevesinde dokozoflar, gerçekliği göz ardı eden, ortaya koyduğu gündelik pratikler ve epistemolojik kabulleri açısından "sabit fikir"lerin temsili olarak kullanılmaktadır. Günümüzde bilgiye ulaşımın bu kadar kolay olmasına karşın hala toplumsal sorunlar üzerine kendini tek yönlü bir kavrayışa sıkıştırarak bilimin gerçekliğini inkâr eden ve sanıları yeniden üreten pratikler de aynı kapsamda değerlendirilebilir. Bourdieu'nün "doxa" ('sabitfikir') adını verdiği sanılar aracılığı ile tahakkümcü eylemleri, sosyal topluma uygulayarak varlıkları onaylanıyor. Yani işin özünde toplumsallaşmak ve ortak inançlara koşulsuz bağlanmamız yatıyor. Bu patrikler sayesinde egemen olan toplum üzerinde tahakküm kurabilme kudretine sahiptir. Başka bir deyişle egemen olan medya ve doksozoflar aracılığıyla meşru olmayan davranışlarını saklama maharetine sahip olmuş oluyor.

Bourdieu'nün düşünümsellik ilkesi bağlamında bilgi, toplumsal dünyada yaygın olan ve yeniden üretilebilen kanaatlerden toplum bireylerini uzak tutar. Bu noktada günlük hayatın rutinine ve akışına kendini kaptırmış bireyin top- 
lumsal dünyanın dayattığı ön kabullerden, ideolojilerden ve basmakalıp genel geçer kanaatlerden arınmasına yardımcı olur. Toplum, doksozoflar tarafından kurgulanan simülasyondan ve bu genel geçer yargılardan kurtulduğu anda gerçek bilgiye erişebilir. Bu durumda mevcut bilgi birikimi muhafaza edilmeli ve her imkânda yükseltilmeli. Bilgi sahiplerinin toplumsal özerk alanlara girmeleri sağlanmalı ve epistemolojik şartlarda üretilen bilgiye erişim ve paylaşım kolaylığı sağlanmalı. Bilgi sahiplerinin ifade ve eleştiri araçlarını (kitle iletişim) kullanabilmelerinin önü açılmalı ve bu alanlarda doxa'lar yerine bilginin kendini yeniden üretmesi sağlanmalıdır. Ancak toplum gerçekleri bu şekilde yalın haliyle görebilir ve doxa'nın simgesel şiddetinin ardına saklanmış tahakküm mekanizmalarının oyununu anlayabilir, öznesi devlet olan bütün cümlelerin teolojik cümleler olduğunun farkına varabilir.

\section{Kaynakça}

Angeles, P. A. (1981). A Dictionary of Philosophy. New York: Barnes \& Noble Books. Aktan, C. C. ve Tunç, M. (1998). "Bilgi Toplumu ve Türkiye". Yeni Türkiye Dergisi. (Ocak-Şubat). 118-134.

Alpan, A. S. (19 Aralık 2014). "Yeni Türkiye'nin Kanaat Teknisyenleri ya da Doksozoflar". Sol Haber. http://haber.sol.org.tr/toplum/aytek-soner-alpan-yazdi-yeni-turkiyenin-kanaat-teknisyenleri-ya-da-doksozoflar-103442. 2 Mayıs 2019.

Baker, U. (2015). Kanaatlerden Imajlara: Duygular Sosyolojine Doğru. İstanbul: iletişim Yayınları.

Baran, G. B. (1997). iletişim Sosyolojisi. Ankara: Afşaroğlu Matbaası.

Baudrillard, J. (2011). Simülakrlar ve Simülasyon. (O. Adanır, çev.). Ankara: Doğu Batı Yayınları.

Bell, D. (1976). The Coming of Post Industrial Society: A Venture in Social Forecasting. New York: Basic Books

-- (1976). Welcome to the Post Industrial Society: Physics Today. 46-49.

Bourdieu, P. (1988). Homo Academicus. (P. Collier, çev.). Cambridge: Polity Books.

(1991). Language and Symbolic Power. (G. Raymond ve M. Adamson, çev.). Cambridge: Polity Books.

(1993). The Field of Cultural Production: Essays on Art and Literature. Cambridge: Polity Books.

-- (1998). On Television and Journalism. Londra: Pluto Press.

-- (2000). Pascalian Me Ditations. (R. Nice, çev.). Cambridge: Polity Books.

-- (2000). Televizyon Üzerine. (T. Ilgaz, çev.). İstanbul: Yapı Kredi Yayınları.

- (2005). The Social Structures of The Economy. Cambridge: Polity Books.

-- (2006). Karşı Ateşler. (H. Yücel, çev.). İstanbul: Yapı Kredi Yayınları.

(2013). Pratik Nedenler: Eylem Kuramı Üzerine. (H. U. Tanrı̈ver, çev.). Adı- 
yaman: Hil Yayınları.

(2014). Seçilmiş Metinler. (L. Ünsaldı, çev.). Ankara: Heretik Yayınları.

Bourdieu, P. ve Passeron, J. C. (1977). Reproduction in Education, Societyand Culture. (R. Nice, çev.). London: Sage Publications.

(1979). The Inheritors, French Students and their Relation to Culture. (R. Nice, çev.). Chicago: University of Chicago Press.

Bourdieu, P. ve Wacquant, L. (1992). An Invitation to Reflexive Sociology. (L. Wacquant, çev.). Cambridge: Polity.

Cevizci, A. (1999). Paradigma Felsefe Sözlüğü. İstanbul: Paradigma Yayınları.

Çakır, M. (2018). Bilgi Toplumu Tartışmaları. İstanbul: Parles Yayınları.

Çüçen, K. (2003). "Bilgi Kuramına Giriş". Bilimname. 2.

Demir, A. (2005). "The Relationship of Idea and Particulars: Episteme vs Doxa". Bülent Ecevit Üniversitesi Ilahiyat Fakültesi Dergisi. 2(2). 285-300.

Eagleton, T. (1991). Ideoloji. (M. Özcan, çev.). i̇stanbul: Ayrıntı Yayınları.

"Enformasyon”. (tarih yok.). Türk Dil Kurumu Güncel Türkçe Sözlük. http://www.tdk. gov.tr/index.php?option=com_bts\&view=bts\&kategori1=veritbn\&kelimesec=113227. 14 Nisan 2019.

Erdoğan, i. (2005). "Kitle iletişiminde Pozitivist Ampirik Geleneğin Kuruluşu: Lazarsfeld ve Yönetimsel Araştırmalar". Gazi Üniversitesi iletişim Dergisi. 20(2). 1-48.

Göker, E. (2011). Komplo Teoriciliğinin Tuhaf Sabitfikri: Komplo Kullanma Kılavuzu. İstanbul: Sharjah Sanat Vakfı.

Herman, E. ve Chomsky, N. (1998), Medya Halka Nasıl Evet Dedirtir: Kitle iletişim Araçlarının Ekonomi Politiği. (B. Akyoldaş, çev.). İstanbul: Minevra Yayınları.

Jones, D. (23 Temmuz 2013). "Türkiye'de Medya Üzerindeki Baskı Sürüyor". Amerika'nın Sesi. https://www.amerikaninsesi.com/a/turkiye-de-medya-uzerindeki-baski-suruyor/1707501.html. 5 Mayıs 2019.

Katz, E. (2000). "Media Multiplication and Social Segmentation". Ethical Perspectives. $7.122-132$.

Keleş, Ö. T. (2012). "Kanaat Önderi Kavramının "Yeni" Mecrası". Sinekolaj. http:// www.sinekolaj.com/makaleler/24/Kanaat_Onderi_Kavraminin_YENI_mecrasi.html. 7 Mayıs 2019.

Kınık, A. M. (2013). Gelişen Web Teknolojileri ve Sosyal Medya Bağımlılığı: Sosyal Medya. Konya: Çizgi Kitabevi.

Kurban, D. ve Sözeri, C. ( 2012). “Türkiye'de Medyanın Ekonomi Politiği: Sektör Analizi". TESEV Medya Raporları Serisi. (47-105). İstanbul: TESEV Yayınları.

Lippmann, W. (1993). Public Opinion: iletişim Modelleri. (M. Küçükkurt, çev.). Ankara: Imaj Yayınları.

Luhmann, N. (2000). The Reality of the Mass Media. California: Stanford University Press. 
McLuhan, M. ve Povers, R. B. (2001). Global Köy. (B. Öcal Düzgören, çev.). i̇stanbul: Scala Yayıncilık.

Mengüşoğlu, T. (2013). Felsefeye Girişs. i̇stanbul: Remzi Kitabevi.

Neumann, N. E. (1998). Kamuoyu Suskunluk Sarmalının Keşfi. (M. Özkök, çev.). Ankara: Dost Kitabevi

Orwell, G. (2001). Bin Dokuz Yüz Seksen Dört. İstanbul: Can Yayınları.

Oskay, Ü. (1973). Kitle Haberleşme Teorilerine Girişs. 281. Ankara: Ankara Üniversitesi Siyasal Bilgiler Fakültesi Yayınları.

Öker, Z. (2003). Kurgusal Dünyanın Gölgesinde Bir Unutkan: Jean Baudrillard. İstanbul: Su Yayınları.

Parlak, i. ve Değirmenci, N. (2015). "Zaman Gazetesi Köşe Yazarlarının Bir Rol Değişim Göstergesi Olarak Bourdieucü Bağlamda Söylemsel Dönüşümleri (2011'den 2014'e)". Galatasaray Üniversitesi ileti-ş-im Dergisi. 23. 9-38. DOI: 10,16878/gsuilet.285311.

Parlak, i. ve Tangün, A. Y. (2018). "Kapana Kısıımışken: Siyaset İmkânı”. Toplum ve Bilim Dergisi. 146. 5-31.

Parlak, I. ve Yıldırım, Y. (2014). Medya Aracılığıyla Siyasal Sınırlar Üretmek. Bursa: Dora Yayınları.

Platon. (2011). Menon. (A. Cemgil, çev.). İstanbul: Remzi Kitabevi.

Rigby, B. (1993). "Heteronomy and Autonomy in Bourdieu's Les Règles de l'Art". French Cultural Studies. 4. 271.

Sözeri, C. (2005). Türkiye'de Medya-iktidar ilişskileri: Sorunlar ve Öneriler. ìstanbul: istanbul Enstitüsü Yayınları.

Sütçü, S. C. ve Bayrakçı, S. (2014). "Sosyal Medya Gazeteleri Nasıl Etkiliyor? Haberlerin Twitter'de Yayılması Üzerine Bir Araştırma". The Turkish Online Journal of Design, Art and Communication-TOJDAC. 4(2). 39-53.

Törenli, N. (2004). Enformasyon Toplumu ve Küreselleşme Sürecinde Türkiye. Ankara: Bilim ve Sanat Yayınları.

Turhan, G. D. (2017). "Dijital Aktivizm”. Journal of Süleyman Demirel University Institute of Social Sciences. 1(26). 26-44.

Türk, B. H. (2016). "Sihirden Nefret Eden Bir ilüzyonist: Bourdieu, Gelenek ve İdeoloji". G. Çeğin, E. Göker, A. Arlı, Ü. Tatlıcan (der.) Ocak ve Zanaat. (605-626). istanbul: iletişim Yayınları.

Ural, Ş. (2012). "Enformasyon Kavramı Üzerine”. Türk Kütüphaneciliği Dergisi. 3. 536-547.

Yıldız, H. (2014). “Paul Lazarsfeld ve Harold Lasswell'in Temel Düşünce ve Yöntem Anlayışları". Medya Araştırmaları 2014 (istanbul Üniversitesi) Blogspot. http://2014hit.blogspot.com/2014/12/paul-lazarsfeld-ve-harold-lasswellin. html. 4 Mayıs 2019.

Yüksel, A. H. (1994). ikna Edici iletişim. 94. Eskişehir: Eskişehir Anadolu Üniversitesi Eğitim, Sağlık ve Bilimsel Araştırma Çalışmaları Vakfı Yayınları. 